$\begin{array}{lcl}\text { Bentham OPEN } \\ \text { CrossMark } & \text { Content list available at: www.benthamopen.com/MEDJ/ } \\ \text { DOI: } 10.2174 / 1874220301603010288 & \text { Open } \\ \text { Medicine } \\ \text { lournal }\end{array}$

REVIEW ARTICLE

\title{
The Use of LASER and its Further Development in Varying Aspects of Surgery
}

\author{
DJ Jordan ${ }^{1}, \mathrm{P} \mathrm{Mafi}^{2, *}, \mathrm{R} \mathrm{Mafi}^{3}, \mathrm{M} \mathrm{Malahias}^{4}$ and A El Gawad ${ }^{1}$ \\ ${ }^{\text {I}}$ Department of Plastic Surgery, Whiston Hospital, Liverpool, UK \\ ${ }^{2}$ Barts and The London NHS Trust, Whipps Cross University Hospital, London, UK \\ ${ }^{3}$ Nuffield Department of Orthopaedics, Rheumatology and Musculoskeletal Sciences, University of Oxford, Oxford, UK \\ ${ }^{4}$ Department of Plastic Surgery, Heart of England NHS Foundation Trust, Birmingham, UK
}

Received: May 23, 2015

Revised: September 17, 2016

Accepted: September 17, 2016

\begin{abstract}
Lasers are now common place in day to day life and have been used across the sciences since their description as far back as 1917. Initially met with some sceptism, their use in medicine and in particular the surgical specialty has only increased. Their use in the future is also likely to expand as we continue to improve their efficiency and technology surrounding them.
\end{abstract}

This review aims to introduce lasers to the novice. The topic of lasers is vast and complex, but we aim to give enough information for the reader to understand how lasers are designed, how they were created, as well as a summary of their current use in medicine.

Keywords: Laser, Surgery, Medicine, Optical maser.

\section{INTRODUCTION}

The acronym laser or LASER stands for "light amplification by stimulated emission of radiation" and its name accredited to Gordon Gould in 1957. Before this time the laser represented the 'optical MASER,' another acronym meaning "microwave amplification by stimulated emission of radiation." However, both applications found their origins at the beginning of that century and in 1917 most famously, Albert Einstein put forward his theory of 'stimulated emission'.

This review aims to introduce lasers to the novice. The topic of lasers is vast and complex, but we aim to give enough information for the reader to understand how lasers are designed, how they were created, as well as a summary of their current use in medicine.

\section{LASER; THE PHYSICS}

Visible light describes the form of electromagnetic radiation whose waves are visible to the human eye. Out with this range, the electromagnetic spectrum continues and amongst others include ultraviolet and infrared wavelength forms. Electromagnetic radiation is absorbed as it travels, particularly by biological tissues, and when absorbed can be described as having photochemical or thermal properties. Excessive radiation energy can also destroy tissue resulting in a mechanical effect.

Light will travel in a straight line, or ray, unless it is disturbed. In a general space, this light disperses and so reduces its intensity. The idea behind lasers is maximising the concentration of light for an end 'destructive force.' This is created by the use of a single colour, or wavelength, through a narrow beam and allowing an additive effect on its

\footnotetext{
* Address correspondence to this author at the Barts and The London NHS Trust, Whipps Cross University Hospital, London, UK; Tel/Fax: + 44(0)1244366265; E-mail: hy9pm@hyms.sc.uk
} 
destination.

These concepts are fundamental in laser use and are described as creating a 'monochromatic,' 'collimated' and 'coherent' light.

By using light of a specific wavelength, absorption is minimised except for the targeted substance. Specifically a laser light is coherent (all the light waves are in phase) and monochromatic (single wavelength). Furthermore, they travel in the same direction and are therefore said to be collimated. Irradiance is another term referring to the high radiant potential of the laser per unit area, due to its concentration in a narrow special band.

The laser light is created by stimulating a known substance (media) to absorb energy. As this substance is excited, the electrons in the media move to a higher energy level. This unstable state causes the electron to return to its normal state immediately and in doing so it emits energy in the form of a photon. The term 'population inversion' describes the number of atoms in the media in the excited state versus the number in their normal, or ground, state.

If this photon stimulates a similar media atom still in its unstable state a further photon is released, and so stimulated emission of photons is created. As the media is made of specific atoms, the photons released by each atom are of a single wavelength. This 'knock on' effect allows the subsequent same wavelength photon to be released in the same direction and at a certain time allowing coherence through the whole media.

\section{LASER; LASING}

The media of a laser is excited by firing a light (pumping) through it. The photons generated by the media, are then reflected within a 'cavity' of mirrors resulting in an amplification of the photons, and thus energy. This cascade effect moves the photons down the laser until they reach a partial mirror where some of the photons are released. This forms the laser output, and when focused can result in a higher power density. The light produced in this process is concentrated in a very narrow spectrum of wavelengths and the purest monochromatic light available (Fig. 1).

The medium, or 'lasing media,' is required to be excited to release photons. This medium is usually either a gas, liquid, crystal or a semiconductor. There are various methods of exciting the lasing medium including high voltage discharge, continuous light, light from a flash lamp, radio-frequency radiation and even light from another laser.

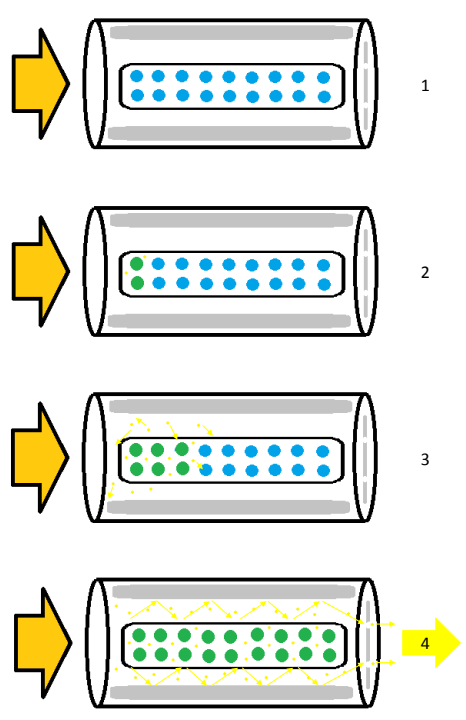

Fig. (1). 1) Light is pumped into the laser cavity stimulating atoms 2) These atoms will release photons as they return to their normal state, upon which they are re-stimulated by the pumping light. 3) These photons initially move haphazardly but stimulate further photon production. 4) The photons are reflected by a series of mirrors (grey) which allow the photons to cascade down the media and laser cavity toward the 'laser' and half-mirror. The 'light' that passes through is at this point all of one photon source (monochromatic), moving in the same direction (collimated) and speed (coherent) and so the laser light is produced. 


\section{LASER; HISTORY OF ITS DISCOVERY AND APPLICATION}

In 1900 Max Plank found, during his studies on the radiancy of light, frequency and temperature, that light is a form of electromagnetic radiation [1]. Previous to this the scientific knowledge of light was merely confined to observing its behaviour and characteristics. However, the mechanism by which light was generated was still unknown.

In 1917, Albert Einstein described the theory of stimulated emission in his publication "on quantum theory of radiation" [2]. This proposed that:

1. Light travels in units of energy called photons, and;

2. Most atoms exist in a standard ground energy stage $\left(\mathrm{E}_{0}\right)$, however, a small number of these naturally occur at higher energy levels $\left(\mathrm{E}_{1}, \mathrm{E}_{2}, \mathrm{E}_{3}, \ldots \mathrm{E}_{\mathrm{n}}\right.$.

Einstein proposed that by adding energy to atoms in $\mathrm{E}_{0}$ state, they could be excited to a higher energy level. Following their excitation to a higher energy level, they return or fall to their original energy level E. During this process, the atoms emit the energy they acquired spontaneously in the form of photons or electromagnetic waves. This formed the basis of stimulated emission which is a core concept in the development of lasers (Fig. 2).

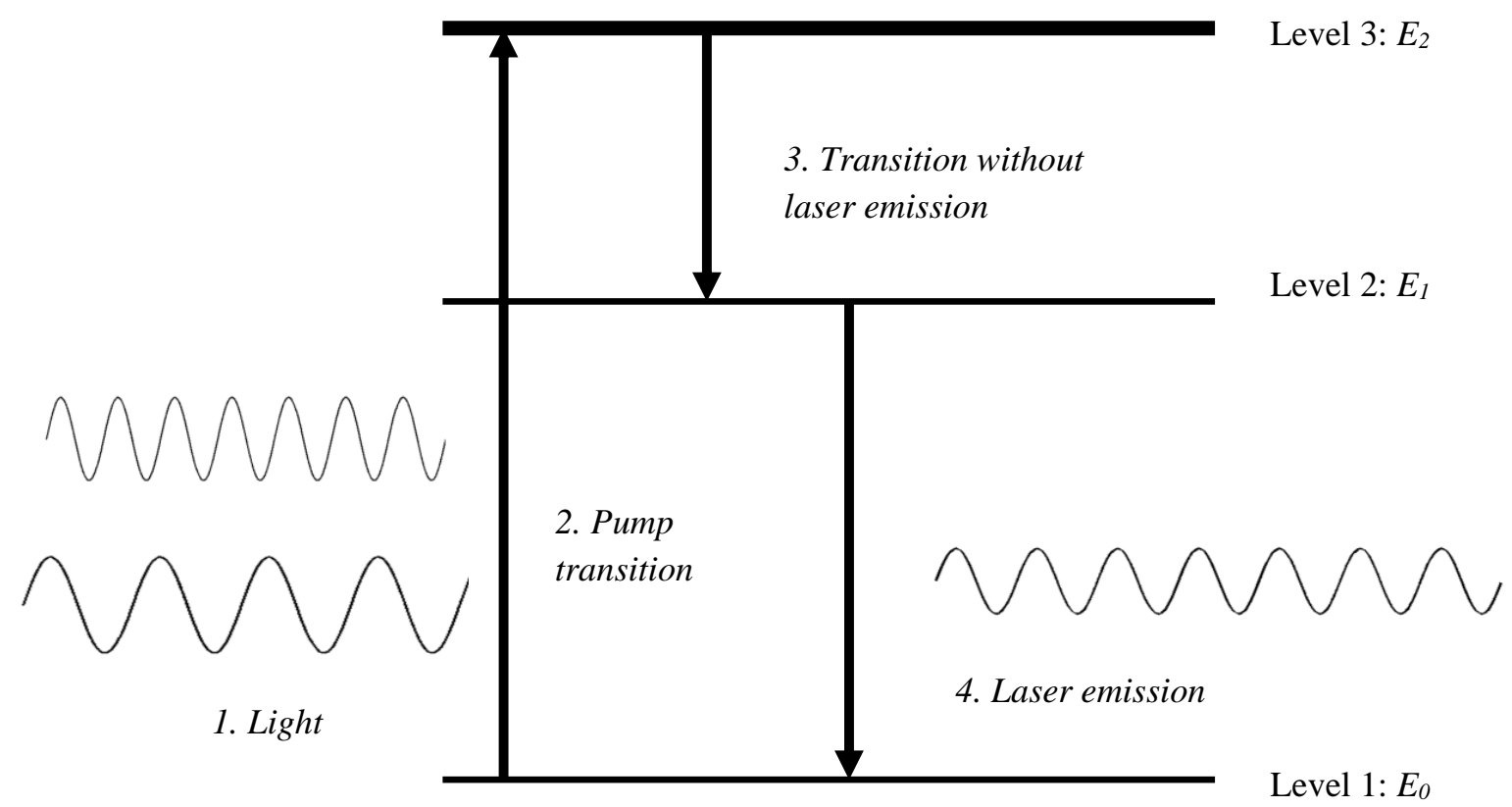

Fig. (2). Transition of light for excitation of atoms to higher energy states E1 and E2 in the process of Laser emission.

During the Second World War, scientists developed an interest in radar equipment and the microwave spectrum of light. In the post war era physicists were looking to amplify stimulated emission at a wavelength shorter than microwave spectrum, with Charles Townes building the first MASER in 1954 at the Columbia University in New York. At the same time in Lebedev laboratories in Moscow, Alexander Prokhorov and Nikolai Basov built a maser prototype. This led to the 3 men sharing the 1964 Nobel Prize for Physics for their research in the field of stimulated emission [3].

Forty three years after Einstein proposed his quantum theory of radiation, on $26^{\text {th }}$ of May 1960, Dr. Theodor Harold Maiman demonstrated the first operational laser [4]. He introduced the first visible light laser using a silver coated ruby crystal, flashlamps and mirrors.

Gases such as nitrogen, Carbon dioxide $\left(\mathrm{CO}_{2}\right)$ and combined Helium-Neon (He-Ne) were the key media used in the first generation of lasers. In 1961 the first He-Ne laser (wavelength $1.15 \mathrm{~nm}$ ) was developed by Ali Javan [5]. In the same year the first Neodymium laser was invented [6]. Geusis et al. [7] published on the $1^{\text {st }}$ laser using YttriumAluminium-Garnet (YAG laser) in 1964. Other gas lasers were introduced by Patel $\left(\mathrm{CO}_{2}\right.$ laser) [8] and Bridges (argon laser) [9]. It was not until 1966 where Soarokin and Lankard [10] built the first ruby-based dye laser, that liquid 
materials were used as the active medium.

As the spectrum of media has increased, so has the use of lasers across industry. It did not take long before lasers were incorporated into medicine for their therapeutic use. Today they are used across a breadth of medicine and surgical specialties, and their use and demand is only expanding.

\section{LASER; LASER USE IN MEDICINE}

The ancient Greeks and Egyptians are believed to have used sunlight as a therapy for treating illness. Today, lasers are applied in medicine for both diagnostic and therapeutic interventions, with their wavelengths ranging from infrared to UV [11]. A selected list of laser applications can be found in Table 1 [12 - 45].

Several factors mediate laser's interaction with the human tissue: absorption, scattering, pulsed versus continuous wave. Water is the primary absorbing medium at wavelengths greater than $1 \mathrm{~mm}$. Other absorbers include haemoglobin and proteins in the blood and melanin skin pigment. Similar to the way in which the absorption of different wavelengths of light changes the colour seen, the use of dyes allow a therapeutic manipulation and selective control of which tissues are targeted. An example of this would be in the treatment of oesophageal or urinary tract carcinomatous tumours where hematoporphyrin dye is used as a photosensitizer in photodynamic therapy to absorb in waves in the range of $630 \mathrm{~nm}$ [46 - 49].

Table 1. Selected applications of laser in medicine.

\begin{tabular}{|c|c|c|}
\hline Speciality & Laser type examples & Use \\
\hline Surgery in General & $\mathrm{CO}_{2}, \mathrm{Nd}: Y A G, \mathrm{Ho}: Y A G$ & $\begin{array}{c}\text { Haemostasis } \\
\text { Sealing of Lymphatics } \\
\text { Cutting }\end{array}$ \\
\hline Dermatology and Plastic Surgery & $\begin{array}{c}\mathrm{CO}_{2} \text {, Nd:YAG, KTP, Diode, Pulsed dye, Ruby, Alexandrite, } \\
\text { Erbium:YAG, Thulium fiber }\end{array}$ & $\begin{array}{c}\text { Vascular/pigmented lesions [12] } \\
\text { Hair removal } \\
\text { Photo-rejuvenation } \\
\text { Tattoo removal } \\
\text { Body contouring/liposuction }[13,14] \\
\text { Scar therapy }[15,16] \\
\text { Lasar ablation/resurfacing } \\
\text { e.g. acne/rhinophyma [17] } \\
\text { Burn excision[18] }\end{array}$ \\
\hline ENT & $\mathrm{CO}_{2}, \mathrm{Nd}: \mathrm{YAG}, \mathrm{KTP}$, Diode & $\begin{array}{c}\text { Microlaryngeal/vocal chords } \\
\text { Respiratory papillomas } \\
\text { Middle ear } \\
\text { Turbinates } \\
\text { Polyps } \\
\text { Sinus surgery }\end{array}$ \\
\hline Gastroenterology & Nd:YAG, Diode & $\begin{array}{c}\text { Recanalisation of oesophagus } \\
\text { Tumour excision/biopsy } \\
\text { Actively bleeding ulcers } \\
\text { Liver disease } \\
\text { Stones; biliary [19] }\end{array}$ \\
\hline Gynaecology & $\mathrm{CO}_{2}, \mathrm{Nd}: Y A G$, Diode & $\begin{array}{c}\text { External - condylomas } \\
\text { Laparoscopic treatment } \\
\text { Hysteroscopic treatment } \\
\text { Foetoscopic treatment } \\
\text { Colposcopic treatment } \\
\text { Papillomas }\end{array}$ \\
\hline Neurosurgery & Infared & $\begin{array}{c}\text { Peripheral neuropathy[20] } \\
\text { Nerve repair [21] } \\
\text { Tissue/tumour ablation [22] } \\
\text { Discectomy [23] } \\
\text { Cerebrovascular therapy [24,25] }\end{array}$ \\
\hline Opthamology & Nd:YAG, Argon, Krypton, Excimer, Erbium:YAG & $\begin{array}{l}\text { Diabetic retinopathy } \\
\text { Macular degeneration } \\
\text { Retinal vein occlusion } \\
\text { Iridectomy } \\
\text { Corneal ablation } \\
\text { Keratoplasty }\end{array}$ \\
\hline
\end{tabular}




\begin{tabular}{|c|c|c|}
\hline Speciality & Laser type examples & Use \\
\hline Oral and Maxillofacial Surgery & $\mathrm{CO}_{2}, \mathrm{Nd}: \mathrm{YAG}$, Diode & $\begin{array}{l}\text { Tumour excision/biopsy } \\
\text { Papillomas } \\
\text { Peri-implantitis [26] }\end{array}$ \\
\hline Orthopaedic Surgery & Nd:YAG, Ho:YAG, Blue violet & $\begin{array}{c}\text { Smoothing cartilage } \\
\text { Knee surgery } \\
\text { Lumbar disc decompression }\end{array}$ \\
\hline Thoracic Surgery & $\mathrm{CO}_{2}, \mathrm{Nd}: Y A G$, Excimer & $\begin{array}{l}\text { Recanalisation trachea/upper airways } \\
\text { Cardiac ablation } \\
\text { Pacemaker implantation/Lead extraction [27] }\end{array}$ \\
\hline Urology & Nd:YAG, Ho:YAG, KTP, Diode, Pulsed dye & $\begin{array}{c}\text { Stones; bladder/kidney } \\
\text { Tumour excision/biopsy } \\
\text { Ureteric strictures } \\
\text { Bladder neck incisions } \\
\text { Prostate coagulation [28] } \\
\text { Prostate resection[28] }\end{array}$ \\
\hline Vascular & Nd:YAG & $\begin{array}{l}\text { Endovascular ablation [29] } \\
\text { Laser Doppler flowmetry }\end{array}$ \\
\hline Oncology & $\mathrm{CO}_{2}, \mathrm{Nd}: Y A G, \mathrm{KTP}$, Gold vapour & $\begin{array}{c}\text { Tumour excision/biopsy } \\
\text { Photodynamic therapy (PDT) } \\
\text { Palliative tumour ablation }\end{array}$ \\
\hline Pain Therapy & Diode, Low level laser therapy & $\begin{array}{c}\text { Wound healing [30] } \\
\text { Acute/Chronic pain therapy }[31,32] \\
\text { Acupuncture }[33,34]\end{array}$ \\
\hline Microscopy/Genetics & & Laser capture microdissection [35 - 37] \\
\hline Other & Low level laser therapy & $\begin{array}{c}\text { Psychology adjunct [38] } \\
\text { Imaging [39] } \\
\text { Implant fabrication [40 - 42] Onychomycosis [43] } \\
\text { Musculoskeletal therapy [44] }\end{array}$ \\
\hline
\end{tabular}

Revised from Shokrollahi K, Raymond E, Murison MSC. Lasers; Principles and Surgical Applications [45]

Scattering, on the other hand, limits the tissue penetration depth. Scattering describes when photons spread to outside the central target area/main beam. This could be desirable if treating a large tumour where a deep depth and large width are needed, but also harmful if treating a small, well defined area as normal cells can be damaged. The consequence of this is unpredictable and on a spectrum. This may have zero impact on the cell, or cause cell mutation, or death. This property is currently being studied extensively with the purpose of obtaining high resolution imagery in the screening for breast cancer [50].

The power range of lasers can be described as pulsed or continuous waveforms. Although some lasers are limited to one of these forms, the latter can be used to deliver a high energy quickly. This is useful for instance, in tissue ablation where evaporation of the top layer of cells is more useful than a continuous wave where the heat may be absorbed away from the target tissue. By adjusting the pulse frequency and thermal diffusion that occurs, the depth of laser effect can be determined.

The first continuous wave laser was introduced in 1970 in the form of an argon-pumped dye laser. There was huge excitement around creating more advanced lasers and extending their application. When researchers noted the ability of laser to burn through tissue it did not take long until they were applied in the surgical field. The laser energy was measured in "Gillette-units" referring to the amount of razors penetrated by one laser pulse [51]. Despite its destructive potential it was first used in medicine to do the exact opposite. Initially it was utilised by an ophthalmologist in a retinal repair $[52,53]$.

For the beginner in laser use, the treatment outcome of each laser type can be altered by modifying three aspects of the laser setup. It should be noted that some lasers have one of these settings set and so may be unable to be modified. The first feature that can be changed is the actual power generated by the laser and this is usually described in joules. This energy output can then be delivered to the target area in a short or a longer time period. This is what is described by the pulse duration. Lastly, some lasers such as the pulsed dye, the hand-piece can be changed. The hand-piece generally relates to the spot size or zone, which is to be treated. For the pulsed dye laser, which delivers the energy in a conical fashion, a wider spot size corresponds to a deeper 'destruction pattern.'

The joules delivered and pulse duration can modify the tissue effect. A low density thermal energy can be used to induce tissue coagulation, which is useful for tissue debulking. Alternatively a higher density thermal energy given quickly causes vaporisation of the tissue cells, as well as a degree of coagulation necrosis to the surrounding cells. 
Modifying this delivery can result in an incisional laser function to a more destructive ablation.

\section{LASER; SPECIFIC USES}

Not long after their first introduction lasers conquered a place in the heart of medicine. Their applications became a significant part of diagnosis and treatment with the initial applications of ruby, argon, $\mathrm{YAG}, \mathrm{CO}_{2}$, lasers taking place in 1964. Despite this, their potential dangers were noted early on some of which included $\mathrm{CO}_{2}$ laser tissue vaporization and YAG-induced coagulative necrosis. Visible lasers such as ruby and argon were noted to produce haemostatic coagulation.

These initial concerns were later to be utilised in different fields for a therapeutic effect. Today laser is used across many medical and surgical specialties, with varying media used in each practice.

Dermatology, specifically, has found a wide range of use for lasers. Examples include skin treatments such as spider naevi removal, hair removal, removal of tattoos and treating skin lesions [54 - 57]. Another well-known application is in urology where laser lithotripsy targets the removal of kidney and gallbladder stones.

Ophthalmology, general surgery and dentistry have also fully embraced laser therapy. Ophthalmologists were among the very first adaptors of this technology. This is understandable as the eye is designed to react to light! The fact that the eye is designed to allow light enter it allows many treatments of intra-ocular conditions. Argon lasers have been in use for numerous years in the treatment of retinal detachment and retinal haemorrhages, although the increasing availability of YAG and $\mathrm{CO}_{2}$ lasers, which can both incise tissue and coagulate bleeding, has led to their widespread and early use in general surgery [58 - 61]. In dentistry a different version of the YAG laser has been introduced for the purpose of reducing the post-procedural pain (Erbium[Er:YAG] as opposed to Neodymium [Ng:YAG]).

With the growing interest in lasers and advances in their development many diagnostic procedures such as flow cytometry with clinical applications such as immunophenotyping and measuring DNA content have developed throughout the years. Flow cytometry uses two laser beams to excite molecular particles in cells which can be utilised in cell analysis and sorting. Furthermore Flow cytometry is used in genetic engineering as it is capable of separating large numbers of chromosomes, which in turn can be used in creating recombinant DNA reference libraries.

The applications of lasers in medical imaging have been of great significance. New laser imaging technologies such as the optical coherence tomography (OCT) are being used in creating a special resolutions of tissue in the submillimetre range [62]. The newer version of OCT are specially accurate and sensitive that they are capable of detecting abnormalities such as atherosclerosis in its early stages. Another clinical application of OCT is its role in diagnosing a vast array of retinal macular pathologies. It has been shown to be able to produce accurate images of embryos, GI tract, skin and the vascular system. The resolution of MRI and ultrasound images are limited to $1 \mathrm{~mm}$ range, although a new technique using spin polarised gases is being investigated to improve MRI images of the brain and lungs [63].

For those using lasers, there are complications and adverse effects described. Chiefly, for skin use in particular, these include erythema, blistering and burns to the skin and subsequent scarring. There are risks of thinning or thickening of the skin, infection and hypersensitivity to the treatment. Hypo and hyperpigmentation of the skin has been described, particularly if sun exposure occurs peri-therapy. Patients should also be made aware of partial- or nonresolution of symptoms and currently keloids. Scleroderma, systemic lupus erythema and isotretinoin use should be considered as contraindications to laser resurfacing.

\section{LASER; FUTURE APPLICATIONS}

One field of medicine which will laser would hopefully transform most, in both diagnosis and morbidity, is oncology. Raman spectroscopy is a relatively new use for laser technology and has shown promising results in imaging malignancy by differentiating the light reflected back by the normal and abnormal tissue in the human body. It provides a non-invasive imaging tool [64 - 66].

The use of current therapies will hopefully develop. Since its first use in dermatology and plastic surgery, its use has developed from benign skin lesions, through pigmented lesions, and is now being used in the treatment of primary and metastatic diseases, including squamous cell carcinoma and malignant melanoma [12, 54 - 57].

Photodynamic therapy is an application which may offer future treatment to not only skin malignancies but also the gastro-oesophageal, genito-urinary and respiratory tract neoplasias [47 - 50], with clinically based and laboratory experiments focusing on malignancy specific laser therapy [67 - 69]. Likewise, the use of photo-coagulation to treat 
breast and hepatic cancerous and benign lesions, potentially a tissue salvaging day case procedure, is being explored $[47,69]$.

The use of lasers in localised infections, involving bacteria and virus infected cell destruction, is theoretically sound and an area for future examination [47, 70 - 74].

In theory lasers can have a therapeutic effect against localised infections if light and photosensitising material can be delivered to the infected area. This makes treatment of infections such as MRSA-infected skin ulcers, or mouth ulcers with laser a very realistic possibility in the near future. Another possibility is the treatment of Helicobacter Pylori infection. It can be photosensitized with the use of methylene blue and photodynamic therapy can be applied endoscopically. Although the treatment of viruses can be technically more challenging, there is scope for sensitizing or even eradicating genital warts [47].

Tissue regeneration (skin, bone and cartilage) and fusion [75 - 80] is being commented on with signs that low-level laser therapy can induce and accelerate bone healing properties in particular [81 - 85]. Renno et al. [82] investigated the effect of laser irradiation on osteoblasts and malignant osteosarcomas in vitro and suggest that different cell lines respond differently to particular wavelengths and energy intensities. They demonstrated a significant increase in the proliferation of osteoblasts at $830-\mathrm{nm}$ laser irradiation, but a decrease at 780 -nm laser irradiation. Hawkins and Abrahamse [83] have suggested that with the correct number of exposures and energy density of helium-neon laser to wounded fibroblasts mitochondrial activity can be enhanced which can in turn positively influence cellular migration and proliferation without causing additional stress to already damaged or impaired cells.

The creation of the femtosecond laser [84 - 88] has helped reduce the amount of light exposure received by treated cells and tissues, and opens an option of generic therapy with new lasers being designed to create more accurate dissection. Hess et al. compared the cutting effects of scalpel, $\mathrm{CO}_{2}$ laser and the picosecond infrared laser-(PIRL) in cadaveric human vocal cords and concluded that the PIRL laser offers promising future clinical applications as it proved to cause close to no damage on the tissue that was being cut, avoiding coagulation and other forms of tissue insult [89].

Microneedles, created using lasers, as well as laser treatments to skin allow a more pain free administration of intravenous and subcutaneous medications compared to traditional methods, enhancing drug delivery [90 - 93 ].

This is specifically useful in the delivery of vaccines where a cutaneous route often induces a stronger immune response compared to a muscular route. Chen et al. discuss the advantage of using lasers in the delivery of vaccines, which can increase the immune response without any significant local or systemic adverse effects [90]. They argue that the desirable characteristics of such lasers, such as convenience, safety and their cost-effectiveness makes them a desirable subject for clinical studies in the near future.

The option for robotic assisted laser use is also an area gaining support [94, 95].

Another area is of course the laboratory use of lasers. The potential for lasers to hold and move microscopic units allowing individual cell isolation, and the ability of laser imaging allowing individual molecules to be highlighted and potentially targeted for pharmaceutical therapy will only develop in the future. In vivo microscopy is a possibility, again allowing less tissue destruction and increasing the specificity of surgical procedures [96].

The future offers a wider use of lasers, likely to involve less invasive and more specific targeting, potentially to a cellular level.

There has recently been a development in Intense Pulse Light Sources (IPL's), which have similar indications to lasers but use a non-coherent 'broad spectrum' light ranging from the ultraviolet to infared regions. They are commonly used for hair removal currently but may have an increased spectrum of use [95, 96].

\section{CONCLUSION}

Lasers have developed greatly in their variability and application since Einstein's theoretical ideas and the first use of a laser by Theodor Maiman at the end of the 1950's [2, 4].

In terms of future innovation, laser use has the potential to be developed in regard to new wavelength bands, improvement in the average output power, peak pulse energy and power levels, as well as improvements in cost, power, and size efficiency.

These parameters will help medicine use lasers across a wider breadth of specialities with simpler, cheaper and smaller laser applications allowing a wider acceptance of laser use and introduction to smaller hospital units. 


\section{CONFLICT OF INTEREST}

The author confirms that this article content has no conflict of interest.

\section{ACKNOWLEDGEMENTS}

Declared none.

\section{REFERENCES}

[1] Dicke R. Coherence in spontaneous radiation processes. Phys Rev 1954; 93 : 99. [http://dx.doi.org/10.1103/PhysRev.93.99]

[2] Einstein A. Zur Quantentheorie der Strahlung. Phys Z 1917; 18: 121-8.

[3] Hecht J. Laser Pioneers. Oxford: Elsevier 1991.

[4] Maiman T. Stimulated optical radiation in ruby. Nature 1960; 187: 493-4. [http://dx.doi.org/10.1038/187493a0]

[5] Hecht J. Laser Pioneers. New York: Academic Press 1992.

[6] White A, Rigden J. Continuous gas maser operation in the visible. Proc IRE 1962; 50: 1697.

[7] Johnson L, Nassau K. Infrared fluorescence and stimulated CaWO4. Proc IRE 1961; 49: 1704-6.

[8] Geusic J, Marcos H, Uitert LV. Laser oscilations in Nd-doped yttrium aluminium, yttrium gallium and gadolinium garnets. Appl Phys Lett 1964; 4: 182 [http://dx.doi.org/10.1063/1.1753928]

[9] Patel C, Farlane RM, Faust W. Selective excitation through vibrational energy transfer and optical maser action in $\mathrm{N}_{2}-\mathrm{CO}_{2}$. Physiol Rev 1964 ; 13(617-619)

[10] Bridges W. Laser oscillation in singly ionized argon in the visible spectrum. Appl Phys Lett 1964; 5: 39. [http://dx.doi.org/10.1063/1.1754038]

[11] Deutsch T. Lasers and optics in health care. Proc IEEE 1997; 85: 1797. [http://dx.doi.org/10.1109/5.649658]

[12] Khan R. Lasers in plastic surgery. J Tissue Viability 2001; 11(3): 103-7, 110-2. [http://dx.doi.org/10.1016/S0965-206X(01)80039-5] [PMID: 11949612]

[13] Nestor MS, Newburger J, Zarraga MB. Body contouring using 635-nm low level laser therapy. Semin Cutan Med Surg 2013; 32(1): 35-40. [PMID: 24049928]

[14] Jackson RF, Roche GC, Shanks SC. A double-blind, placebo-controlled randomized trial evaluating the ability of low-level laser therapy to improve the appearance of cellulite. Lasers Surg Med 2013; 45(3): 141-7. [http://dx.doi.org/10.1002/1sm.22119] [PMID: 23508376]

[15] Anderson RR, Donelan MB, Hivnor C, et al. Laser treatment of traumatic scars with an emphasis on ablative fractional laser resurfacing: consensus report. JAMA Dermatol 2014; 150(2): 187-93. [http://dx.doi.org/10.1001/jamadermatol.2013.7761] [PMID: 24336931]

[16] Gauglitz GG. Management of keloids and hypertrophic scars: current and emerging options. Clin Cosmet Investig Dermatol 2013; 6 : 103-14. [http://dx.doi.org/10.2147/CCID.S35252] [PMID: 23637546]

[17] Ong MW, Bashir SJ. Fractional laser resurfacing for acne scars: a review. Br J Dermatol 2012; 166(6): 1160-9. [http://dx.doi.org/10.1111/j.1365-2133.2012.10870.x] [PMID: 22296284]

[18] Kaiser M, Yafi A, Cinat M, Choi B, Durkin AJ. Noninvasive assessment of burn wound severity using optical technology: a review of current and future modalities. Burns 2011;37(3): 377-86. [http://dx.doi.org/10.1016/j.burns.2010.11.012] [PMID: 21185123]

[19] Ierardi AM, Fontana F, Petrillo M, et al. Percutaneous transhepatic endoscopic holmium laser lithotripsy for intrahepatic and choledochal biliary stones. Int J Surg 2013; 11(Suppl. 1): S36-9. [http://dx.doi.org/10.1016/S1743-9191(13)60011-4] [PMID: 24380548]

[20] Kochetova OA, Malkova NY. Opportunity to use the low-level laser therapy in the treatment of the occupational peripheral nervous system diseases (review of literature). Med Tr Prom Ekol 2013; (8): 37-9. [PMID: 24340760]

[21] Rubis LM. Chiropractic management of Bell palsy with low level laser and manipulation: a case report. J Chiropr Med 2013; 12(4): $288-91$. [http://dx.doi.org/10.1016/j.jcm.2013.10.001] [PMID: 24396332]

[22] Gonzalez-Martinez J, Vadera S, Mullin J, et al. Robot-assisted stereotactic laser ablation in medically intractable epilepsy: operative technique. Neurosurgery 2014; 10(Suppl. 2): 167-72. [http://dx.doi.org/10.1227/NEU.0000000000000286] [PMID: 24448180] 
[23] Singh V, Manchikanti L, Benyamin RM, Helm S, Hirsch JA. Percutaneous lumbar laser disc decompression: a systematic review of current evidence. Pain Physician 2009; 12(3): 573-88. [PMID: 19461824]

[24] Crocker M, Walsh D, Epaliyanage P, Tolias CM. Excimer laser-assisted non-occlusive cerebral vascular Anastomosis (ELANA): review of the first UK experience. Br J Neurosurg 2010; 24(2): 148-55. [http://dx.doi.org/10.3109/02688690903506127] [PMID: 20121536]

[25] Langer DJ, Van Der Zwan A, Vajkoczy P, Kivipelto L, Van Doormaal TP, Tulleken CA. Excimer laser-assisted nonocclusive anastomosis. An emerging technology for use in the creation of intracranial-intracranial and extracranial-intracranial cerebral bypass. Neurosurg Focus 2008; 24(2): E6. [http://dx.doi.org/10.3171/FOC/2008/24/2/E6] [PMID: 18275301]

[26] Kotsakis GA, Konstantinidis I, Karoussis IK, Ma X, Chu H. A systematic review and meta-analysis of the effect of various laser wavelengths in the treatment of peri-implantitis. J Peridontol 2014; 85(9): 1203-13. [http://dx.doi.org/10.1902/jop.2014.130610]

[27] Goyal SK, Ellis CR, Ball SK, et al. High-risk lead removal by planned sequential transvenous laser extraction and minimally invasive right thoracotomy. J Cardiovasc Electrophysiol 2014; 25(6): 617-21. [http://dx.doi.org/10.1111/jce.12368] [PMID: 24446764]

[28] Osterberg EC, Choi BB. Review of current laser therapies for the treatment of benign prostatic hyperplasia. Korean J Urol 2013 ; 54(6): 351-8. [http://dx.doi.org/10.4111/kju.2013.54.6.351] [PMID: 23789041]

[29] Hardman RL, Rochon PJ. Role of interventional radiologists in the management of lower extremity venous insufficiency. Semin Intervent Radiol 2013; 30(4): 388-93. [http://dx.doi.org/10.1055/s-0033-1359733] [PMID: 24436566]

[30] Camões Barbosa A, Simões H, Lorga S, Mendes M. Low-level laser therapy in the treatment of diabetic ulcers: an evidence problem. Acta Med Port 2011; 24(Suppl. 4): 875-80. [PMID: 22863495]

[31] Al Rashoud AS, Abboud RJ, Wang W, Wigderowitz C. Efficacy of low-level laser therapy applied at acupuncture points in knee osteoarthritis: a randomised double-blind comparative trial. Physiotherapy 2014; 100(3): 242-8. [PMID: 24418801]

[32] Knapp DJ. Postherpetic neuralgia: case study of class 4 laser therapy intervention. Clin J Pain 2013; 29(10): e6-9. [http://dx.doi.org/10.1097/AJP.0b013e31828b8ef8] [PMID: 24384987]

[33] Manca A, Limonta E, Pilurzi G, et al. Ultrasound and laser as stand-alone therapies for myofascial trigger points: a randomized, double-blind, placebo-controlled study. Physiother Res Int 2014; 19(3): 166-75. [http://dx.doi.org/10.1002/pri.1580] [PMID: 24382836]

[34] Ferreira DC, De Rossi A, Torres CP, Galo R, Paula-Silva FW, Queiroz AM. Effect of laser acupuncture and auricular acupressure in a child with trismus as a sequela of medulloblastoma. Acupunct Med 2014; 32(2): 190-3. [http://dx.doi.org/10.1136/acupmed-2013-010484] [PMID: 24384541]

[35] Esposito G. Complementary techniques: laser capture microdissectionincreasing specificity of gene expression profiling of cancer specimens. Adv Exp Med Biol 2007; 593: 54-65.

[http://dx.doi.org/10.1007/978-0-387-39978-2_6] [PMID: 17265716]

[36] Fend F, Raffeld M. Laser capture microdissection in pathology. J Clin Pathol 2000; 53(9): 666-72. [http://dx.doi.org/10.1136/jcp.53.9.666] [PMID: 11041055]

[37] Cheng L, Zhang S, MacLennan GT, et al. Laser-assisted microdissection in translational research: theory, technical considerations, and future applications. Appl Immunohistochem Mol Morphol 2013; 21(1): 31-47. [PMID: 22495368]

[38] White AR, Rampes H, Liu JP, Stead LF, Campbell J. Acupuncture and related interventions for smoking cessation. Cochrane Database Syst Rev 2014; 1(1): CD000009. [PMID: 24459016]

[39] Carroll FE. Pulsed, Tunable, Monochromatic X-rays: Medical and Non-Medical Applications. In: Duarte FJ, Ed. Tunable Laser Applications. $2^{\text {nd }}$ ed. Boca Raton: CRC Press 2008; pp. 281-310. [http://dx.doi.org/10.1201/9781420060584.ch10]

[40] Chen F, Zhang D, Yang Q, et al. Bioinspired wetting surface via laser microfabrication. ACS Appl Mater Interfaces 2013; 5(15): 6777-92. [http://dx.doi.org/10.1021/am401677z] [PMID: 23865499]

[41] Kawano T, Prananingrum W, Ishida Y, Goto T, et al. Blue-violet laser modification of titania treated titanium: antibacterial and osteoinductive effects. PLoS One 2013; 8(12): e84327-6792. [http://dx.doi.org/10.1371/journal.pone.0084327.]

[42] Allegrini S Jr, Yoshimoto M, Salles MB, de Almeida Bressiani AH. Biologic response to titanium implants with laser-treated surfaces. Int J Oral Maxillofac Implants 2014; 29(1): 63-70. [http://dx.doi.org/10.11607/jomi.3213] [PMID: 24451855] 
[43] Westerberg DP, Voyack MJ. Onychomycosis: Current trends in diagnosis and treatment. Am Fam Physician 2013; 88(11): 762-70. [PMID: 24364524]

[44] Dos Reis FA, da Silva BA, Laraia EM, et al. Effects of pre or post-exercise low-level laser therapy (830 nm) on skeletal muscle fatigue and biochemical markers of recovery in humans: double-blind placebo-controlled trial. Photomed Laser Surg 2014. Jan 23. [Epub ahead of print]

[45] Shokrollahi K, Raymond E, Murison M. Lasers; principles and surgical applications. J Surg 2004; 2(1): 28-34 [http://dx.doi.org/10.1016/S1743-9191(06)60023-X]

[46] Kallaway C, Almond LM, Barr H, et al. Advances in the clinical application of Raman spectroscopy for cancer diagnostics. Photodiagn Photodyn Ther 2013; 10(3): 207-19.

[http://dx.doi.org/10.1016/j.pdpdt.2013.01.008] [PMID: 23993846]

[47] Brown SG. Science, medicine, and the future: New techniques in laser therapy. BMJ 1998; 316: 754-7.

[48] Deprez PH. Future directions in EUS-guided tissue acquisition. Gastrointest Endosc Clin N Am 2014; 24(1): 143-9. [http://dx.doi.org/10.1016/j.giec.2013.08.004] [PMID: 24215765]

[49] Crous AM, Abrahamse H. Lung cancer stem cells and low-intensity laser irradiation: a potential future therapy? Stem Cell Res Ther 2013; 4(5): 129 . [http://dx.doi.org/10.1186/scrt340] [PMID: 24153107]

[50] Valcavi R, Piana S, Bortolan GS, Lai R, Barbieri V, Negro R. Ultrasound-guided percutaneous laser ablation of papillary thyroid microcarcinoma: a feasibility study on three cases with pathological and immunohistochemical evaluation. Thyroid 2013; 23(12): 1578-82. [http://dx.doi.org/10.1089/thy.2013.0279] [PMID: 23978269]

[51] Sorokin P, Lankard J. Flashlamp excitation of organic dye lasers-a short communication. IBM J Res Develop 1967; $11: 148$. [http://dx.doi.org/10.1147/rd.112.0148]

[52] Bromberg J. The laser in America, 1950-1970. The MIT Press: Cambridge 1991.

[53] Zinn KM. Clinical aspects of ophthalmic argon laser. Lasers Surg Med 1981; 1(4): 289-322. [http://dx.doi.org/10.1002/1sm.1900010405] [PMID: 7199607]

[54] Brehmer F, Ulrich M, Haenssle HA. Strategies for early recognition of cutaneous melanoma-present and future. Dermatol Pract Concept 2012; 2(3): 203a06. Jul 31

[55] Grootendorst DJ, Jose J, Wouters MW, et al. First experiences of photoacoustic imaging for detection of melanoma metastases in resected human lymph nodes. Lasers Surg Med 2012; 44(7): 541-9. [http://dx.doi.org/10.1002/lsm.22058] [PMID: 22886491]

[56] Ferris LK, Harris RJ. New diagnostic aids for melanoma. Dermatol Clin 2012; 30(3): 535-45. [http://dx.doi.org/10.1016/j.det.2012.04.012] [PMID: 22800557]

[57] Ziefle S, Schüle D, Breuninger H, Schippert W, Moehrle M. Confocal laser scanning microscopy vs. 3-dimensional histologic imaging in basal cell carcinoma. Arch Dermatol 2010; 146(8): 843-7.

[http://dx.doi.org/10.1001/archdermatol.2010.191] [PMID: 20713814]

[58] Carruth J, McKenzie A. Medical lasers:science and clinical practice. Bristol: Adasm Hilger 1986.

[59] Goldman L. The biomedical laser: technology and clinical applications. New York: Springer Verlag 1981. [http://dx.doi.org/10.1007/978-1-4612-5922-0]

[60] Atsumi K. New frontiers in laser medicine and surgery. Amsterdam: Elsevier 1983.

[61] Hillenkamp F, Pretassi R, Sacchi C. Lasers in biology and medicine. New York: Plenum Publishing 1979.

[62] Tearney G, Brezinski M, Bourma B, Boppart S, Pitris C, Southem J. In vivo endoscopic optical biopsy with optical coherence tomography. Science 1997; 276: 2037-9.

[63] Mittleman H, Black R, Saam B, et al. MR imaging with hyperpolarized 3He gas. Magn Reson Med 1995; 33(5): 271-5. [PMID: 7707920]

[64] Canetta E, Riches A, Borger E, Herrington S, et al. Discrimination of bladder cancer cells from normal urothelial cells with high specificity and sensitivity: Combined application of atomic force microscopy and modulated Raman spectroscopy Acta Biomater 2014; pii: S1742-7061(13): 00662-4. Jan 7

[http://dx.doi.org/10.1016/j.actbio.2013.12.057]

[65] Kast RE, Tucker SC, Killian K, Trexler M, Honn KV, Auner GW. Emerging technology: applications of Raman spectroscopy for prostate cancer. Cancer Metastasis Rev 2014; 33(2-3): 673-93. [http://dx.doi.org/10.1007/s10555-013-9489-6] [PMID: 24510129]

[66] Kallaway C, Almond LM, Barr H, et al. Advances in the clinical application of Raman spectroscopy for cancer diagnostics. Photodiagn Photodyn Ther 2013; 10(3): 207-19.

[http://dx.doi.org/10.1016/j.pdpdt.2013.01.008] [PMID: 23993846]

[67] Hawasli AH, Bagade S, Shimony JS, Miller-Thomas M, Leuthardt EC. Magnetic resonance imaging-guided focused laser interstitial thermal therapy for intracranial lesions: single-institution series. Neurosurgery 2013; 73(6): 1007-17. [http://dx.doi.org/10.1227/NEU.0000000000000144] [PMID: 24056317] 
[68] Brüchner K, Beyreuther E, Baumann M, Krause M, Oppelt M, Pawelke J. Establishment of a small animal tumour model for in vivo studies with low energy laser accelerated particles. Radiat Oncol 2014; 9(1): 57. [http://dx.doi.org/10.1186/1748-717X-9-57] [PMID: 24533586]

[69] Ashiq MG, Saeed MA, Tahir BA, Ibrahim N, Nadeem M. Breast cancer therapy by laser-induced Coulomb explosion of gold nanoparticles. Chin J Cancer Res 2013; 25(6): 756-61. [PMID: 24385705]

[70] Raab O. Ueber die wirkung fluorescierenden stoffe auf infusiorien. Z Biol 1900; 39: 524-46.

[71] Gupta A, Avci P, Dai T, Huang YY, Hamblin MR. Ultraviolet radiation in wound care: sterilization and stimulation. Adv Wound Care (New Rochelle) 2013; 2(8): 422-37. [http://dx.doi.org/10.1089/wound.2012.0366] [PMID: 24527357]

[72] Tsen SW, Kingsley DH, Poweleit C, et al. Studies of inactivation mechanism of non-enveloped icosahedral virus by a visible ultrashort pulsed laser. Virol J 2014; 11(1): 20. [http://dx.doi.org/10.1186/1743-422X-11-20] [PMID: 24495489]

[73] Vatansever F, Ferraresi C, de Sousa MV, et al. Can biowarfare agents be defeated with light? Virulence 2013; 4(8): 796-825. [http://dx.doi.org/10.4161/viru.26475] [PMID: 24067444]

[74] Krespi YP, Kizhner V, Kara CO. Laser-induced microbial reduction in acute bacterial rhinosinusitis. Am J Rhinol Allergy 2009; 23(6): e29-32.

[http://dx.doi.org/10.2500/ajra.2009.23.3404] [PMID: 19958597]

[75] Meier JC, Bleier BS. Novel techniques and the future of skull base reconstruction. Adv Otorhinolaryngol 2013; 74: 174-83. [http://dx.doi.org/10.1159/000342294] [PMID: 23257563]

[76] Bleier BS, Cohen NA, Chiu AG, OMalley BW Jr, Doghramji L, Palmer JN. Endonasal laser tissue welding: first human experience. Am J Rhinol Allergy 2010; 24(3): 244-6.

[http://dx.doi.org/10.2500/ajra.2010.24.3463] [PMID: 20537294]

[77] Matteini P, Ratto F, Rossi F, Pini R. Emerging concepts of laser-activated nanoparticles for tissue bonding. J Biomed Opt 2012; 17(1): 010701.

[http://dx.doi.org/10.1117/1.JBO.17.1.010701] [PMID: 22352632]

[78] Capon A, Mordon S. Can thermal lasers promote skin wound healing? Am J Clin Dermatol 2003; 4(1): 1-12. [http://dx.doi.org/10.2165/00128071-200304010-00001] [PMID: 12477368]

[79] Sobol E, Shekhter A, Guller A, Baum O, Baskov A. Laser-induced regeneration of cartilage. J Biomed Opt 2011 ; 16(8): 080902. [http://dx.doi.org/10.1117/1.3614565] [PMID: 21895308]

[80] Esposito G, Rossi F, Matteini P, et al. Present status and new perspectives in laser welding of vascular tissues. J Biol Regul Homeost Agents 2011; 25(2): 145-52. [PMID: 21880202]

[81] Mizokami T, Aoki K, Iwabuchi S, Kasai K, et al. Low reactive level laser therapy - A clinical study: Relationship between pain attenuation and the serotonergic mechanism. Laser Ther 1993; 5(4): 165-8. [http://dx.doi.org/10.5978/islsm.93-OR-19]

[82] Renno AC, McDonnell PA, Parizotto NA, Laakso EL. The effects of laser irradiation on osteoblast and osteosarcoma cell proliferation and differentiation in vitro. Photomed Laser Surg 2007; 25(4): 275-80. [http://dx.doi.org/10.1089/pho.2007.2055] [PMID: 17803384]

[83] Hawkins D, Abrahamse H. Effect of multiple exposures of low-level laser therapy on the cellular responses of wounded human skin fibroblasts. Photomed Laser Surg 2006; 24(6): 705-14. [http://dx.doi.org/10.1089/pho.2006.24.705] [PMID: 17199470]

[84] Tracey S, Gracco A. Lasers in Orthodontics. In: Graber LW, Vanarsdall RL, Vig KWL, Eds. Orthodontics current principles and techniques. $5^{\text {th }}$ ed. St. Louis, Mo:: Elsevier Mosby 2012; pp. 1051-73.

[85] Abrahamse H. Regenerative medicine, stem cells, and low-level laser therapy: future directives. Photomed Laser Surg 2012; 30(12): 681-2. [http://dx.doi.org/10.1089/pho.2012.9881] [PMID: 23140266]

[86] Roberts TV, Lawless M, Chan CC, et al. Femtosecond laser cataract surgery: technology and clinical practice. Clin Exp Ophthalmol 2013; 41(2): 180-6. [http://dx.doi.org/10.1111/j.1442-9071.2012.02851.x] [PMID: 22788831]

[87] Sutton G, Bali SJ, Hodge C. Femtosecond cataract surgery: transitioning to laser cataract. Curr Opin Ophthalmol 2013; $24(1)$ : 3-8. [http://dx.doi.org/10.1097/ICU.0b013e32835a936b] [PMID: 23197263]

[88] Kuetemeyer K, Rezgui R, Lubatschowski H, Heisterkamp A. Influence of laser parameters and staining on femtosecond laser-based intracellular nanosurgery. Biomed Opt Express 2010; 1(2): 587-97. [http://dx.doi.org/10.1364/BOE.1.000587] [PMID: 21258492]

[89] Hess M, Hildebrandt MD, Müller F, et al. Picosecond infrared laser (PIRL): an ideal phonomicrosurgical laser? Eur Arch Otorhinolaryngol 2013; 270(11): 2927-37. 
[http://dx.doi.org/10.1007/s00405-013-2561-6] [PMID: 23708442]

[90] Chen X, Wang J, Shah D, Wu MX. An update on the use of laser technology in skin vaccination. Expert Rev Vaccines 2013; 12(11): $1313-23$. [http://dx.doi.org/10.1586/14760584.2013.844070] [PMID: 24127871]

[91] Scheiblhofer S, Thalhamer J, Weiss R. Laser microporation of the skin: prospects for painless application of protective and therapeutic vaccines. Expert Opin Drug Deliv 2013; 10(6): 761-73. [http://dx.doi.org/10.1517/17425247.2013.773970] [PMID: 23425032]

[92] Elsabahy M, Foldvari M. Needle-free gene delivery through the skin: an overview of recent strategies. Curr Pharm Des 2013; 19(41): 7301-15.

[http://dx.doi.org/10.2174/13816128113199990369] [PMID: 23489207]

[93] Yavlovich A, Smith B, Gupta K, Blumenthal R, Puri A. Light-sensitive lipid-based nanoparticles for drug delivery: design principles and future considerations for biological applications. Mol Membr Biol 2010; 27(7): 364-81. [http://dx.doi.org/10.3109/09687688.2010.507788] [PMID: 20939770]

[94] Gonzalez-Martinez J, Vadera S, Mullin J, et al. Robot-assisted stereotactic laser ablation in medically intractable epilepsy: operative technique. Neurosurgery 2014; 10(Suppl. 2): 167-72. [http://dx.doi.org/10.1227/NEU.0000000000000286] [PMID: 24448180]

[95] Jolesz FA. Intraoperative imaging in neurosurgery: where will the future take us? Acta Neurochir Suppl (Wien) 2011; 109: 21-5. [http://dx.doi.org/10.1007/978-3-211-99651-5_4] [PMID: 20960316]

[96] Mooney MA, Zehri AH, Georges JF, Nakaji P. Laser scanning confocal endomicroscopy in the neurosurgical operating room: a review and discussion of future applications. Neurosurg Focus 2014; 36(2): E9. [http://dx.doi.org/10.3171/2013.11.FOCUS13484] [PMID: 24484262]

C) Jordan et al.; Licensee Bentham Open

This is an open access article licensed under the terms of the Creative Commons Attribution-Non-Commercial 4.0 International Public License (CC BY-NC 4.0) (https://creativecommons.org/licenses/by-nc/4.0/legalcode), which permits unrestricted, non-commercial use, distribution and reproduction in any medium, provided the work is properly cited. 